\title{
Hubungan Menarche Dengan Tinggi Badan Pada Mahasiswi Fakultas Kedokteran Universitas YARSI Angkatan 2013 dan 2014
}

\section{Relationship B etween Menarche to Height YARSI University Faculty of Medicine Students Periode 2013 and 2014}

\author{
Luvianti $^{1}$, Qomariyah ${ }^{2}$ \\ Student of Faculty of Medicine, YARSI University, Jakarta \\ ${ }^{2}$ Faculty of Medicine Lecture, YARSI University, Jakarta \\ Korespondensi : E-mail: luvianti23@gmail.com
}

\begin{abstract}
Abstrak
Menarche adalah perdarahan pertama dari uterus yang terjadi pada seorang wanita. Usia menarche dapat bervariasi pada setiap individu dan wilayah. Beberapa penelitian menunjukan perempuan yang mengalami menarche lebih awal mempunyai tinggi badan yang rendah dibandingkan dengan perempuan yang mengalami menarche lambat. Tujuan penelitian ini untuk mengetahui hubungan menarche dengan tinggi badan pada mahasiswi Fakultas Kedokteran Universitas YARSI angkatan 2013-2014. Jumlah sampel penelitian sebanyak 83 mahasiswi. Rentang usia responden yaitu 20-23 tahun. Data akan dianalisa menggunakan metoda Chi Square. Dari hasil penelitian didapatkan rata-rata usia menarche yaitu 12.24 \pm 1.16 tahun dan rata-rata tinggi badan yaitu $157,76 \pm 5.44 \mathrm{~cm}$. Pada uji statistic menggunakan metoda Chi Square didapatkan $P=0.426(p>0.05)$ maka secara statistic tidak terdapat hubungan yang signifikan antara menarche dengan tinggi badan.
\end{abstract}

Kata kunci: Menarche, Height

\begin{abstract}
Menarche is the first menstrual cycle, or the first menstrual bleeding, in female. Age of menarche may vary for each individual and region. Some studies suggest women who experienced early menarche have a short body height compared with women who experience late menarche.

The aim of this study was find out the relationship between menarche and body height at the medical faculty of YARSI university periode 2013 and 2014.

This study was conducted at YARSI University with a total sample of 83 female students with the age range 20-23 years. Data were be analyzed using Chi Square. From the results, the average age of menarche was $12.24 \pm 1.16$ years and the average of body height is $157.76 \pm 5.44 \mathrm{~cm}$. Statistical test using the method Chi Square result $p=0426$ ( $p>0.05$ ), there is not significantly between menarche to height.
\end{abstract}

Keywords : Menarche, Height 


\section{Pendahuluan}

Sebelum seorang wanita siap menjalani masa reproduksi, terdapat masa peralihan dari masa kanak-kanak menuju masa kedewasaan yang lebih dikenal dengan masa pubertas. Secara klinis pubertas dimulai dengan timbulnya ciri-ciri kelamin sekunder, dan berakhir jika sudah ada kemampuan reproduksi. Kejadian yang penting dalam pubertas ialah pertumbuhan badan yang cepat, menarche, dan perubahan psikis (Wiknjosastro, 2009).

Menarche adalah perdarahan pertama dari uterus yang terjadi pada seorang wanita (Wiknjosastro, 2009). Fase datangnya haid ini merupakan suatu peristiwa di mana remaja telah siap secara biologis menjalani fungsi kewanitaannya (Kartono, 2006).

Usia menarche dapat bervariasi pada setiap individu dan wilayah. Beberapa penelitian menunjukkan bahwa usia menarche terjadi lebih cepat. Anak-anak menjadi dewasa setahun lebih awal daripada anak-anak di negara Eropa, ratarata usia menarche menurun dari 14,2 tahun pada tahun 1900 menjadi kira-kira 12,45 tahun (Karapanou \& Papadimitriou dalam Amaliah et. al., 2012). Penelitian Aribowo menunjukkan usia menarche pada siswi SMP di Kabupaten Pati rata-rata adalah 12,2 tahun (Ariwibowo dalam Amaliah et. al., 2012 ).

Hasil penelitian Onland-Moret et.al., (2005) menunjukan perempuan yang mengalami menarche lebih awal, akan tumbuh tinggi lebih cepat. Sebaliknya perempuan yang mengalami menarche lebih awal mempunyai tinggi yang pendek saat dewasa dibandingkan dengan perempuan yang mengalami menarche lambat. Penelitian lain yang dilakukan oleh Gharravi et. al., (2008) di Iran menunjukan bahwa perempuan yang mengalami menarche lebih awal akan tumbuh lebih cepat, namun mencapai tinggi badan yang lebih pendek saat dewasa dibandingkan perempuan yang menarche lebih lama setahun.

Penelitian kohort di Inggris pada tahun 1958 membuktikan bahwa remaja perempuan yang mendapatkan menstruasi pertama pada usia 11 tahun memiliki rata-rata tinggi badan 1,62 $\mathrm{m}$, hal ini berbeda dengan tinggi badan remaja perempuan yang menstruasi pertama setelah usia 11 tahun dengan rata-rata tinggi 1,63 m. Penelitian di Brazil pada tahun 2006 menunjukan tinggi badan saat umur 19 tahun adalah 1,61 $\pm 0,06 \mathrm{~m}$ pada perempuan yang mendapatkan menstruasi pertama sebelum usia 13 tahun dan 1,62 $\pm 0,06 \mathrm{~m}$ pada perempuan yang mendapat menstruasi setelah usia 13 tahun (Gigante et.al., 2006). Wanita yang menarche lebih lambat 1 tahun akan tumbuh lebih tinggi sekitar $0.35 \mathrm{~cm}$ (Onland-Moret et. al., 2005). Hubungan ini dapat di jelaskan oleh penutupan cakram epifisis yang lebih cepat pada wanita yang menarche lebih awal. Hal ini disebabkan wanita yang menarche lebih awal peningkatan estrogen akan terjadi lebih awal yang dapat memicu penutupan cakram epifisis lebih cepat. Menarche yang lambat memungkinkan waktu pertumbuhan tulang panjang lebih lama sebelum epifisis menyatu sehingga tubuh akan lebih tinggi (Onland-Moret et. al., 2005).

Berdasarkan hal tersebut, maka peneliti tertarik untuk mengadakan penelitian mengenai Hubungan Menarche denga Tinggi Badan Pada Mahasiswi Fakultas Kedokteran Universitas YARSI. Tujuan dari penelitian ini yaitu untuk mengetahui hubungan menarche dengan tinggi badan pada mahasiswi Fakultas Kedokteran Universitas YARSI angkatan 2013-2014 dan tinjauan dalam Islam. 


\section{Bahan dan Metode Penelitian}

Penelitian ini merupakan jenis-penelitian kuantitatif yang bersifat non-eksperimental. Rancangan penelitian ini menggunakan desain cross-sectional. variabel dependen yang diamati adalah tinggi badan dan variable independen adallah usia menarche. Sampel pada penelitian ini adalah mahasiswi Fakultas Kedokteran Universitas YARSI angkatan 2013-2014 yang memenui kriteria inklusi yaitu usia $\geq 20$ tahun dan bersedia menjalani penelian ini dengan mengisi lembar inform consent. Kriteia ekslusi pada penelitian ini yaitu mahasiswi yang pernah atau sedang mengalami patah tulang kaki, ataupun kondisi-kondisi yang menyebab-kan tinggi badan tidak dapat diukur. Sampel diambil dengn simpe random sampling. Penetapan sampel dilakukan dengan rumus Slovin dan diapatkan hasil 83. Data nanti akan dianalisi menggunakan metoda Chi Square menggunakan program SPSS 16.0 for windows.

\section{Hasil Penelitian}

Data penelitan diperoleh dari kuesioner dan pengukuran langsung tinggi badan. Berikut ini karakteristik responden dapat dilihat pada Tabel 1.

Tabel 1 Karakteristik Responden

\begin{tabular}{cccc}
\hline \multicolumn{2}{c}{ Karakteristik } & $\mathbf{N}$ & $\%$ \\
\hline Menarche & Dini & 48 & $57.8 \%$ \\
& Terlambat & 35 & $42.2 \%$ \\
\hline Usia saat ini & 20 & 32 & $38.6 \%$ \\
& 21 & 42 & $50.6 \%$ \\
& 22 & 8 & $9.6 \%$ \\
& 23 & 1 & $1.2 \%$ \\
\hline
\end{tabular}

Sumber: Olah Data, 2016

\section{Menarche}

Gambaran usia menarche pada mahasiswi Fakultas Kedokteran Universitas
YARSI angkatan 2013 dan 2014 dapat dilihat pada table berikut:

Berdasarkan tabel 2 didapatkan responden berjumlah 83. Rata-rata usia menarche pada mahasiswi Fakultas Kedokteran Universitas YARSI angkatan 2013 dan 2014 adalah 12, 24 tahun. Mahasiswi dengan usia menarche termuda yaitu 10 tahun dan tertua adalah 15 tahun. Gambaran menarche dini dan lambat dapat dilihat pada tabel 7 .

Pada tabel 2 usia menarche dikelompokan berdasarkan usia menarche dini ( $<13$ tahun) dan menarche lambat ( $\geq 13$ tahun). Mahasiswi yang mengalami menarche dini sebanyak 48 dan menarche lambat 35 . Usia menarche terbanyak yaitu 12 tahun.

\section{Tinggi Badan}

Gambaran tinggi badan pada mahasiswi

Fakultas Kedokteran Universitas YARSI angkatan 2013 dan 2014 dapat dilihat pada table berikut:

Berdasarkan tabel 3 dari 83 responden diketahui bahwa tinggi badan rerata mahasiswi adalah 157,76 cm. Nilai modus menandakan tinggi badan terbanyak yaitu $160 \mathrm{~cm}$. Mahasiswa dengan tinggi badan terendah yaitu $143 \mathrm{~cm}$ dan tertinggi adalah $169 \mathrm{~cm}$.

\section{Hubungan Menarche dengan Tinggi Badan}

Berdasarkan hasil penelitian, terdapat 2 kategori yaitu menarche dini dan menarche lambat serta tinggi badan kurang dari rata-rata yaitu $<158 \mathrm{~cm}$ dan tinggi badan lebih dari ratarata yaitu $\geq 158 \mathrm{~cm}$. Kemudian dilakukan uji statistic dengan Chi Square dan hasilnya dapat dilihat pada tabel berikut:

Hasil uji Chi Square didapatkan nilai $p=$ 0.426 ( $p>0.05)$ maka secara statistic tidak 
terdapat hubungan yang signifikan antara usia menarche dengan tinggi badan.

Table 2. Distribusi Usia Menarche Responden

\begin{tabular}{ccccccc}
\hline Variable & Rata-rata & Median & Modus & $\begin{array}{c}\text { Simpang } \\
\text { Baku }\end{array}$ & Minimum & Maximum \\
\hline $\begin{array}{c}\text { Usia } \\
\text { Menarche }\end{array}$ & 12.24 & 12 & 12 & 1.16 & 10 & 15 \\
\hline
\end{tabular}

Sumber: Olah Data, 2016

Tabel 3. Proporsi Usia Menarche berdasarkan Kategori

\begin{tabular}{|c|c|c|}
\hline Variabel & usia & Jumlah \\
\hline \multirow[t]{3}{*}{ Menarche Dini } & 10 & 5 \\
\hline & 11 & 18 \\
\hline & 12 & 25 \\
\hline Menarche & 13 & 24 \\
\hline \multirow[t]{2}{*}{ Terlambat } & 14 & 9 \\
\hline & 15 & 2 \\
\hline \multicolumn{2}{|c|}{ Total } & 83 \\
\hline
\end{tabular}

Sumber: Olah Data, 2016

Tabel 3. Distribusi Tinggi Badan Responden

\begin{tabular}{lcccccc}
\hline Variabel & Rata-rata & Median & Modus & $\begin{array}{l}\text { Simpang } \\
\text { Baku }\end{array}$ & Minimum & Maximum \\
\hline $\begin{array}{l}\text { Tinggi } \\
\text { Badan }\end{array}$ & $157,76 \mathrm{~cm}$ & $158 \mathrm{~cm}$ & $160 \mathrm{~cm}$ & 5.44 & $143 \mathrm{~cm}$ & $169 \mathrm{~cm}$ \\
\hline \multicolumn{2}{l}{ Sumber: Olah Data, 2016 } & & & & &
\end{tabular}

Tabel 4. Hubungan Menarche dengan Tinggi Badan

\begin{tabular}{|c|c|c|c|c|}
\hline \multirow[t]{3}{*}{ Tinggi Badan } & \multicolumn{2}{|c|}{ Menarche } & \multirow[t]{2}{*}{ Total } & \multirow[t]{2}{*}{$\mathrm{P}$} \\
\hline & Dini & Terlambat & & \\
\hline & $f$ & $f$ & $f$ & \\
\hline $\begin{array}{c}\text { Kurang dari } \\
\text { rata-rata }\end{array}$ & 26 & 15 & 41 & 0.426 \\
\hline $\begin{array}{l}\text { Lebih dari rata- } \\
\text { rata }\end{array}$ & 22 & 20 & 42 & \\
\hline Total & 48 & 35 & 83 & \\
\hline
\end{tabular}

Sumber: Olah Data, 2016 


\section{Diskusi}

Penelitian ini menggunakan metode cross sectional, dimana pengukuran dilakukan satu kali tanpa adanya follow-up sehingga tidak dapat menjelaskan hubungan sebab akibat. Hubungan yang didapatkan hanya menunjukan keterkaitannya saja, tidak berakibat sebab akibat.

\section{Usia Menarche}

Usia menarche dalam penelitian ini mengikuti penelitian yang dilakukan Gigante et. al (2006), yaitu membagi usia menarche menjadi menarche dini ( $<13$ tahun) dan menarche lambat ( $\geq 13$ tahun). Dari hasil penelitian didapatkan usia menarche yang bervariasi antara usia 10-15 tahun. Mahasiswi dengan menarche dini berjumlah 48 dan menarche lambat berjumlah 35 dengan rata-rata usia menarche yaitu 12.24 tahun. Menurut Kartono (2006) dan Wiknjosastro (2009) usia menarche yang bervariasi disebabkan banyak faktor sepetri keturunan, gizi, kesehatan, ras dan lingkungan, yang dapat mempengaruhi cepat atau lambatnya menarche seorang wanita.

\section{Tinggi Badan}

Hasil penelitian ini menunjukan rata-rata tinggi badan mahasiswi Fakultas Kedokteran Universitas YARSI adalah 157.76 $\pm 5.44 \mathrm{~cm}$ dengan rentan tinggi badan dari $143 \mathrm{~cm}$ hingga $169 \mathrm{~cm}$. Hasil ini lebih tinggi dari penelitian yang dilakukan Atmadja yang menyatakan bahwa rata-rata wanita Indonesia dewasa muda adalah $153.72 \pm 6.24$ cm. Menurut Perkins et. al, (2016) tinggi badan dipengaruhi oleh berbagai faktor yaitu genetic, berat badan lahir, seks, nutrisi, lingkungan, penyakit, dan usia menarche. Pada penelitian ini hal yang mungkin menghasilkan rata-rata tinggi badan yang lebih tinggi dari penelitian sebelumnya adalah jumlah populasi yang berbeda. Dimana pada penelitian sebelumnya jumlah populasi berjumlah 150 dengan rentan usia 17-30 tahun sedangkan pada penelitian ini jumlah populasi yaitu 83 dengan rentan usia 20-23 tahun.

\section{Hubungan Menarche dengan Tinggi badan}

Hasil statistic didapatkan $p$ value $=0.426$ yang menunjukan tidak ada hubungan yang bermakna antara usia menarche dengan tinggi badan. Pertumbuhan tinggi badan tidak hanya dipengaruhi oleh usia menarche tetapi terdapat faktor-faktor lain seperti genetik, berat badan lahir, nutrisi, lingkungan dan penyakit (Perkins et. al, 2016).

Hasil penelitian ini tidak sejalan dengan penelitian terdahulu yang dilakukan OnlandMoret et. al. (2005) dan Gigante et. al. (2006) yang menyatakan wanita yang mengalami menarche dini akan mendapatkan tinggi badan yang lebih pendek dibandingkan dengan wanita dengan menarche terlambat. Hal ini dapat dijelaskan karena wanita yang mengalami menarche dini akan lebih cepat terpapar estrogen. Dimana estrogen memicu menutupnya lempeng epifisis lebih cepat sehingga wanita yang mendapat menarche dini mempunyai tinggi badan yang lebih pendek dibandingkan dengan wanita yang mendapat menarche terlambat (Onland-Moret et. al. 2005).

\section{Simpulan dan Saran}

Berdasarkan hasil analisis data pada penelitian hubungan menarche dengan tinggi badan pada mahasiswi Fakultas Kedokteran Universitas YARSI angkatan 2013 dan 2014 dapat disimpulkan bahwa: 
1. Gambaran rata-rata usia menarche mahasiswi Fakultas Kedokteran Universitas YARSI angkatan 2013 dan 2014 adalah 12.24 tahun dengan rentan kejadian usia menarche terbanyak pada usia 12 tahun. Usia menarche termuda 10 tahun dan usia menarche tertua 15 tahun.

2. Rata-rata tinggi badan mahasiswi adalah $157.76 \pm 5.44 \mathrm{~cm}$ dengan tinggi badan terendah adalah $143 \mathrm{~cm}$ dan tertinggi 169 $\mathrm{cm}$.

3. Berdasarkan uji statistic Chi Square tidak ada hubungan bermakna antara usia menarche dengan tinggi badan mahasiswi dengan didapatkan nilai $p=0.426$ ( $p>0.05)$.

Diharapkan dapat dilakukan penelitian lebih lanjut dengan memasukan faktor-faktor lain yang mempengaruhi tinggi badan dengan jumlah sampel yang lebih besar.Ucapan Terimakasih

Ucapan terima kasih disampaikan kepada semua pihak yang telah membantu dalam terlaksananya penelitian ini.

\section{Daftar Pustaka}

Amaliah N, Kencana S dan Bunga Ch.Rosha. 2012. Status Tinggi Badan Pendek Berisiko Terhadap Keterlambatan Usia Menarche Pada Perempuan Remaja Usia 10-15 Tahun (Stunting Increased Risk of Delaying Menarche on Female Adolescent Aged 10-15 Years). Panel Gizi Makan 35(2) hal 150-158.

Gharavi A.M, Gharravi S, Abdoljalal M, Abdolvahab M and Mohammad J.G. 2008. Correlation of age at menarche and height in Iranian student girls living in GorganNortheast of Iran. J Pak Med Assoc Vol. 58 No. 8

Kartono K. 2006. Psikologi wanita. Mengenal Gadis Remaja dan Wanita Dewasa. Bandung: Bandar Maju.

Onland-Moret NC et. al. 2005. Age at Menarche in Relation to Adult Height. American Journal of Epidemiologu Vol.162 No. 7

Wiknjosastro H. 2009. IImu Kandungan. Jakarta: Yayasan Bina Pustaka Sarwono Prawirohardjo 